\section{Effect of Salt Spray Concentration on Growth and Appearance of 'Gracillimus' Maiden Grass and 'Hamelin' Fountain Grass}

\author{
S.M. Scheiber ${ }^{1,4,7}$, David Sandrock ${ }^{2,4}$, Erin Alvarez ${ }^{1,5}$, \\ and Meghan M. Brennan ${ }^{3,6}$
}

AdDITIONAL INDEX wORDs. ornamental grasses, Miscanthus sinensis, Pennisetum alopecuroides

SUMMARY. Salt-tolerant landscape plants are important to ornamental growers, landscapers, and residents in coastal communities. Ornamental grasses are frequently recommended for low-maintenance landscape situations and may be candidates for coastal plantings after they are evaluated for their salt spray tolerance. 'Gracillimus' maiden grass (Miscanthus sinensis) and 'Hamelin' fountain grass (Pennisetum alopecuroides) were subjected to four treatments [100\% seawater salt spray, $\mathbf{5 0 \%}$ seawater salt spray, $\mathbf{2 5 \%}$ seawater salt spray, or $\mathbf{0 \%}$ seawater salt spray ( $100 \%$ deionized water)] applied as a foliar spray. As seawater concentration increased, root, shoot, whole-plant biomass gain, height, inflorescence number, and visual quality decreased for both cultivars; however, fountain grass appears to be slightly more tolerant of salt spray than maiden grass.

A s of 2003,153 million people, $53 \%$ of the United States population, lived in the nation's 673 coastal counties (Crossett et al., 2004). As development increases, landscape plants that tolerate coastal conditions become critically important to the ornamental landscape industry.

Researchers have documented injury from airborne salts to plants growing near the coast (Edwards and Holmes, 1968; Karschon, 1964; Malloch, 1972). Exposure to water with high salt content reduces or inhibits plant growth (Belligno et al., 2002a, b; Marcum, 2001; Qian et al., 2001). Much of the research done in salinity tolerance concerns saline soil or saline irrigation (Alshammary et al., 2004; Belligno et al., 2002a, b; Gulzar et al., 2003; Hunter and $\mathrm{Wu}, 2005$; Marcum, 1999; Marcum et al., 2005), but little research focuses on plant

This work was supported by the Florida Agricultural Expt. Sta.

${ }^{1}$ University of Florida, IFAS, Environmental Horticulture Department, MREC, 2725 Binion Road, Apopka, FL 32703

${ }^{2}$ Oregon State University, Department of Horticulture, 4151 Ag and Life Sciences Building, Corvallis, OR 97331

${ }^{3}$ University of Florida, IFAS, College of Agriculture and Life Sciences, McCarty Hall, Gainesville, FL 32611

${ }^{4}$ Assistant Professor

${ }^{5}$ Graduate Research Assistant.

${ }^{6}$ Coordinator, Statistical Research.

${ }^{7}$ Corresponding author. E-mail: scheiber@ufl.edu. exposure to salt spray under nonsaline irrigation conditions. It is well documented that plants are often more sensitive to saline spray than to salt applied at the root zone (Benes et al., 1996; Bernstein and Francois, 1975; Grattan et al., 1981, 1994; Westcot and Ayers, 1984). In addition, much rates of plants under saline conditions, but few studies consider the aesthetic value of the plants after foliage is exposed to water with high salt concentrations (Marcum et al., 2005). For landscape plantings to be successful, they must not only survive, but meet high aesthetic standards.

Many publications list suitable salt-tolerant ornamental landscape plants, but little quantified information exists for the salt tolerance of individual ornamental grass species. The objective of this experiment was to determine the effect of four concentration rates of salt spray on appearance, inflorescence number, of the research done assesses survival growth, and mortality of two ornamental grass species.

\section{Materials and methods}

On I July 2005, 68 (34 of each cultivar) 2.5-inch-diameter liners of 'Gracillimus' maiden grass and 'Hamelin' fountain grass (Emerald Coast Growers, Pensacola, FL) were potted into 2.58-qt containers [model EU170T5(PE); ITML Horticultural Products, Brantford, ON, Canada] and placed on a bench in a polyethylene greenhouse at the University of Florida Environmental Horticulture Greenhouse Complex in Gainesville, FL (lat. $29^{\circ} 38^{\prime} \mathrm{N}$, long. $82^{\circ} 2 \mathrm{l}^{\prime} \mathrm{W}$; irradiance, $900-$ $\left.1000 \mu \mathrm{mol} \cdot \mathrm{m}^{-2}\right)$. The potting media was 5 peat : 4 pine bark : 1 sand (by volume; Florida Potting Soils, Orlando, FL). Irrigation ( $\mathrm{pH}, 7.6$; electrical conductivity, $0.43 \mathrm{dS} \cdot \mathrm{m}^{-1}$; $\left.\mathrm{Na}, 13.01 \mathrm{mg} \cdot \mathrm{L}^{-1} ; \mathrm{Cl}, 31.78 \mathrm{mg} \cdot \mathrm{L}^{-1}\right]$ was provided by 0.076 -inch i.d. onoff tube/weight emitters (one per container; Chapin Watermatics, Watertown, NY) connected to l-inch-diameter polyethylene pipe. Plants received $0.5 \mathrm{~L}$ water twice daily.

On 7 July 2005, six plants of each cultivar were partitioned into roots and shoots, dried at $70{ }^{\circ} \mathrm{C}$ for 72 h, and weighed. On 12 July 2005 , carbon-filtered seawater (salinity, 31.64 practical salinity units; temperature, $30.92{ }^{\circ} \mathrm{C}$; dissolved $\mathrm{O}_{2}, 8.47$ $\mathrm{mg} \cdot \mathrm{L}^{-1}$; saturation of dissolved $\mathrm{O}_{2}$, $138 \%$; pH, 8.52; specific conductance, $48.4 \mathrm{mmhos} / \mathrm{cm} ; 55.5 \% \mathrm{Cl}$; $30.6 \% \mathrm{Na} ; 3.3 \% \mathrm{Mg} ; 2.8 \% \mathrm{~S}$; $1.3 \% \mathrm{Ca}$; $1.2 \% \mathrm{~K})$ was obtained from the Mote Marine Research Laboratory in Sarasota, FL, separated into four 32-gal containers (Rubbermaid, Fairlawn, $\mathrm{OH})$ and combined with deionized water to achieve the following four seawater salt spray concentration treatment levels: $100 \%$ seawater salt spray ( 1 seawater : 0 deionized), $50 \%$ seawater salt spray (1 seawater : l

\begin{tabular}{llll}
\hline $\begin{array}{l}\text { Units } \\
\begin{array}{l}\text { To convert U.S. to SI, } \\
\text { multiply by }\end{array}\end{array}$ & U.S. unit & SI unit & $\begin{array}{l}\text { To convert SI to U.S., } \\
\text { multiply by }\end{array}$ \\
\hline 0.3048 & $\mathrm{ft}$ & $\mathrm{m}$ & 3.2808 \\
3.7854 & $\mathrm{gal}$ & $\mathrm{L}$ & 0.2642 \\
2.54 & inch $(\mathrm{es})$ & $\mathrm{cm}$ & 0.3937 \\
1 & $\mathrm{mmho} / \mathrm{cm}$ & $\mathrm{dS} \cdot \mathrm{m}^{-1}$ & 1 \\
28.3495 & $\mathrm{oz}$ & $\mathrm{G}$ & 0.0353 \\
1 & $\mathrm{ppm}$ & $\mathrm{mg} \cdot \mathrm{L}^{-1}$ & 1 \\
0.9464 & $\mathrm{qt}$ & $\mathrm{L}$ & 1.0567 \\
$\left({ }^{\circ} \mathrm{F}-32\right) \div 1.8$ & ${ }^{\circ} \mathrm{F}$ & ${ }^{\circ} \mathrm{C}$ & $\left(1.8 \times{ }^{\circ} \mathrm{C}\right)+32$ \\
& & & \\
\hline
\end{tabular}


deionized), $25 \%$ seawater salt spray (1 seawater : 3 deionized), and $0 \%$ seawater salt spray (0 seawater : 1 deionized). Treatment applications began on 13 July 2005 . There were seven single-plant replicates of each cultivar $\times$ seawater salt spray concentration combination. At each application, foliage was sprayed to runoff with a l-L spray bottle. A bottomless 32-gal container was placed over each plant at each application to prevent overspray to adjacent plants. Modified 3-gal plastic nursery containers were inverted and installed as pot covers to prevent salt spray from reaching the potting media.

Height, inflorescence number, and visual rating data were collected bimonthly. Height measurements were recorded for both cultivars using only green foliage; chlorotic and necrotic foliage was not included. Visual ratings conducted by the same three observers at each data collection were based on foliage appearance, with $\mathrm{l}=$ no green foliage, $3=50 \%$ green foliage, and $\mathbf{5}=$ all green foliage. Although quality standards differ, researchers deemed ratings of 1 and 2 as unacceptable, a rating of 3 as marginally acceptable, and ratings of 4 and 5 as acceptable in most professionally maintained landscape situations. In addition, root gain, shoot gain, total biomass gain, and height gain (final - initial) were calculated. Mortality was also monitored throughout the experiment. After 90 d, plants were destructively harvested, partitioned into roots and shoots, dried at $70{ }^{\circ} \mathrm{C}$ for $72 \mathrm{~h}$, and weighed.

Data analysis. The experiment was conducted as a completely randomized design with seven single-plant replicates. Regression equations were calculated for shoot dry weight gain, root dry weight gain, and biomass gain as a function of seawater salt spray concentration for each species. Comparisons were made between species to determine effects of both species and seawater salt spray concentration on dry weight gain. When all equations within a comparison were linear, slopes were compared using single-df contrast, and intercepts were analyzed as suggested by Snedecor and Cochran (1980). For these variables, when at least one of the regression lines was quadratic, data were analyzed as a $2 \times 4$ factorial with two species and four seawater salt spray concentrations. When significant differences were indicated, mean separation was by Fisher's protected LSD (Snedecor and Cochran, 1980)].

Regression equations were also calculated for height and inflorescence number over time at each seawater salt spray concentration for each species. Heights and inflorescence numbers were analyzed separately by species. Comparisons were only made within a species to determine effects of seawater salt spray concentration on height and inflorescence number. When all equations within a comparison were linear, slopes were compared using single-df contrast, and intercepts were analyzed as suggested by Snedecor and Cochran (1980). When at least one of the regression lines was quadratic, data were analyzed as repeated measures separately by species. Analysis was by split plot, with seawater salt spray concentration as the main plot and days after treatment initiation as the subplot. When significant differences were indicated, mean separation was by Fisher's protected LSD
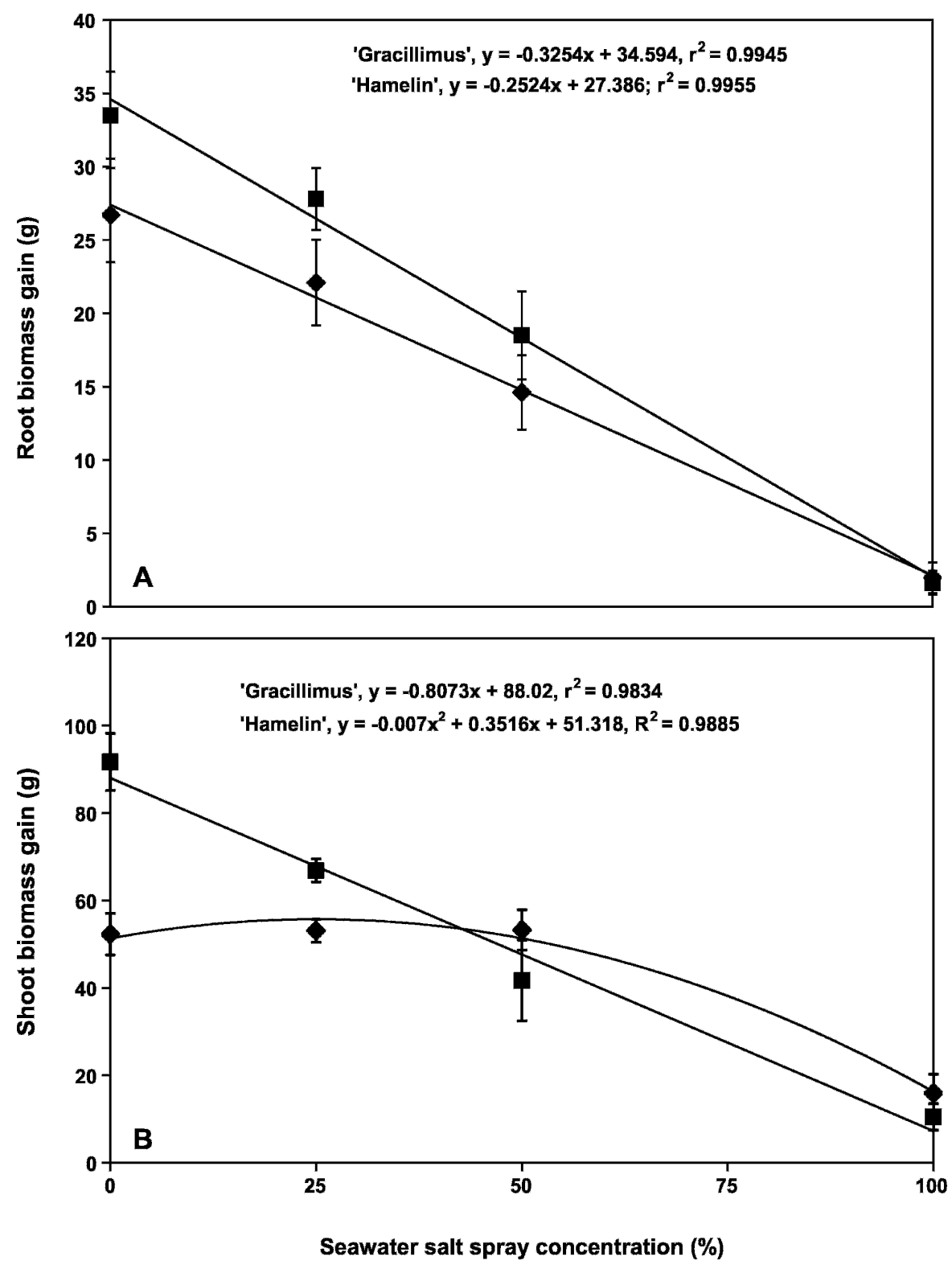

Fig. 1. (A-C) Root biomass gain (A) and shoot biomass gain (B), of ( $\square$ )

'Gracillimus' maiden grass and $(\checkmark)$ 'Hamelin' fountain grass $(n=7)$ grown for $84 \mathrm{~d}$ and treated with four foliar-applied seawater salt spray concentrations $(0 \%, 25 \%$, $50 \%, 100 \%)$. Each point represents the means with \pm SE indicated by SE bars. $1 \mathrm{~g}=$ 0.0353 oz. 
(Snedecor and Cochran, 1980). Overall plant quality was analyzed by NPARIWAY Wilcoxon KruskalWallis. When differences were indicated, means separation was by Wilcoxon two-sample test (Howell, 2004). All analyses were conducted using SAS (version 9.1.3; SAS Institute, Cary, NC).

\section{Results and discussion}

In both 'Gracillimus' maiden grass and 'Hamelin' fountain grass, root, shoot, and whole-plant biomass gain (data not shown) decreased as seawater salt spray concentration increased (Fig. 1). Root biomass gain decreased linearly $(P<0.0001)$ for both 'Gracillimus' maiden grass and 'Hamelin' fountain grass (Fig. 1A), with similar rates of decline between species $(P>0.05)$. Root biomass gain was higher for 'Gracillimus' maiden grass than 'Hamelin' fountain grass among grasses treated with $0 \%$ and $25 \%$ seawater salt spray; however, no species differences existed for grasses treated with $50 \%$ and $100 \%$ seawater salt spray (Fig. 1A). These results agree with previous findings that show increased exposure to salt concentrations ranging from 400 to $1000 \mathrm{~mol} \cdot \mathrm{m}^{-3} \mathrm{NaCl}$ resulted in decreased root weight in mamoncillo (Aeluropus lagopoides)(Gulzar et al., 2003). Alshammary et al. (2004) reported kentucky bluegrass (Poa pratensis) exposed to $1 \mathrm{NaCl}: 1 \mathrm{CaCl}_{2}$ reduced root growth $50 \%$ at $5.8,19.6$, 24.9 , and $41.0 \mathrm{dS} \cdot \mathrm{m}^{-1}$.

Kentucky bluegrass shoot growth was also reduced $50 \%$ at 4.9 , $10.0,20.0$, and $34.9 \mathrm{dS} \cdot \mathrm{m}^{-1}$. Shoot growth and biomass are good indicators of salinity tolerance in both turfgrasses and forage grasses, with many researchers having reported reduced shoot biomass at high salinity levels (Alshammary et al., 2004; Belligno et al., 2002b; Gulzar et al., 2003; Hunter and $\mathrm{Wu}, 2005$; Marcum and Murdoch, 1994; Marcum et al., $2005)$. Shoot biomass gain of 'Gracillimus' maiden grass and 'Hamelin' fountain grass decreased linearly and quadratically respectively as seawater salt spray concentration increased (Fig. 1B), with an interaction occurring between species and seawater salt spray concentration $(P<0.0001)$. Shoot biomass gain was similar for grasses treated with $50 \%$ and $100 \%$ seawater salt spray; however, for grasses treated with $0 \%$ and $25 \%$ seawater salt spray, 'Gracillimus' maiden grass had a higher shoot biomass gain than 'Hamelin' fountain grass (Fig. 1B). It is important to note that the root biomass gain and shoot biomass gain of 'Gracillimus' maiden grass both decreased linearly as seawater salt spray concentration increased. In contrast, as the root biomass gain of 'Hamelin' fountain grass decreased linearly, the shoot biomass remained relatively constant, declining only at $50 \%$ seawater salt spray and higher.
These data indicate that the root biomass gain of each species responded similarly to salt spray treatments whereas the shoot biomass gain of 'Gracillimus' maiden grass demonstrated a greater relative decrease than 'Hamelin' fountain grass. This difference may in part be the result of the differences in overall plant size and architecture as well as growth rate between 'Gracillimus' maiden grass and 'Hamelin' fountain grass. 'Gracillimus' maiden grass is a larger, faster growing plant and would be
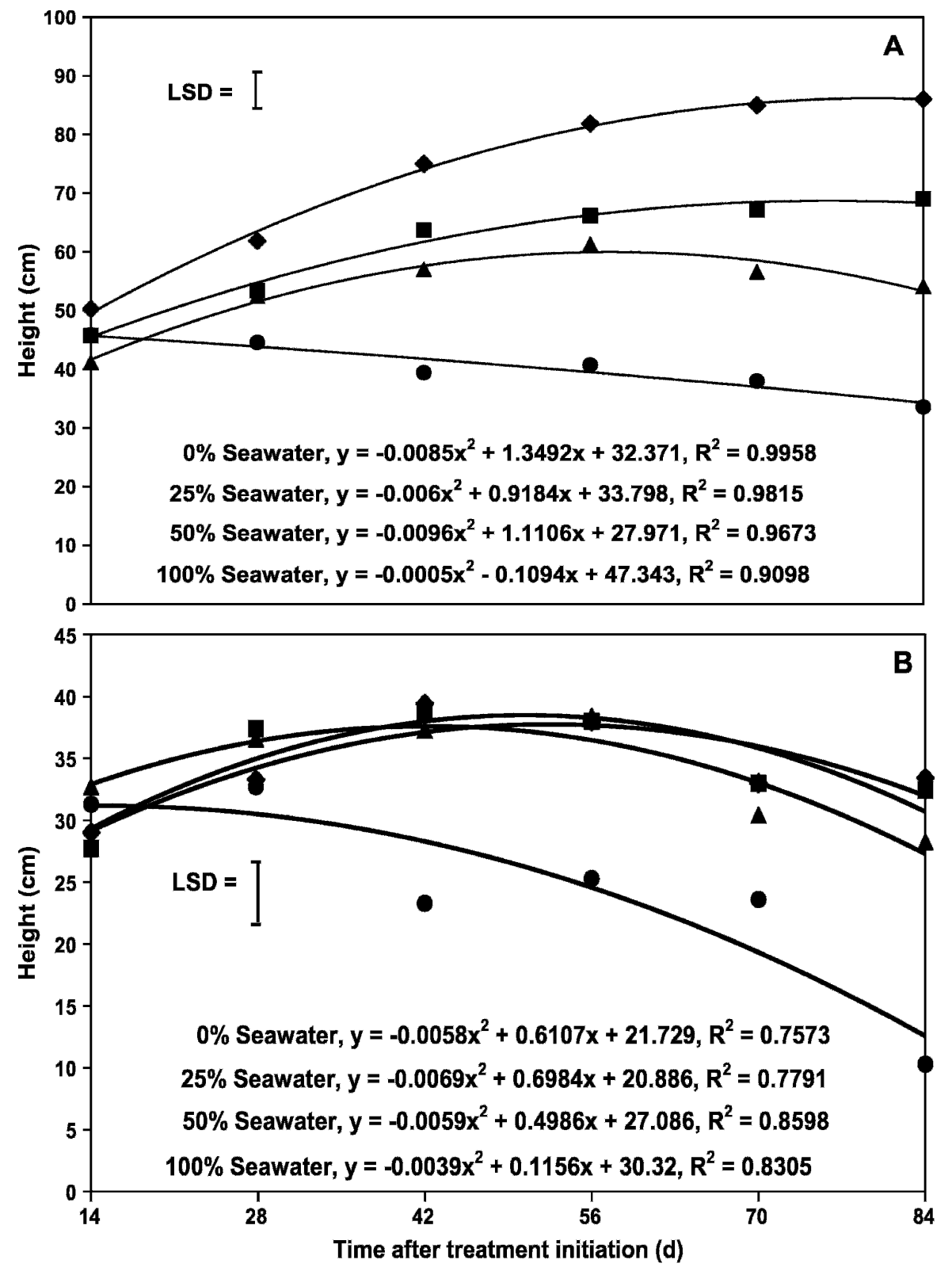

Fig. 2. (A, B) Mean heights for 'Gracillimus' maiden grass (A) and 'Hamelin' fountain grass $(B ; \mathbf{n}=7)$ treated with four foliar-applied seawater salt spray concentrations: $0 \%(\diamond), \mathbf{2 5 \%}(\Delta), \mathbf{5 0 \%}(\square)$, and $\mathbf{1 0 0 \%}(\bullet)$ per event over an 84-d period in central Florida. The vertical bars represent Fisher's protected LSD at $\alpha=0.05 .1 \mathrm{~cm}=0.3937$ inch. 
expected to have greater biomass gain under optimal conditions. Shoot biomass was the major percentage of total biomass gained for each cultivar; therefore, the two displayed similar trends (data not shown).

Height of 'Gracillimus' maiden grass treated with $0 \%, 25 \%$, and $50 \%$ seawater salt spray responded quadratically $(P<0.05$; initially increasing and then leveling off or decreasing) whereas the $100 \%$ seawater salt spray treatments decreased linearly (Fig. 2A). Similar trends were found for 'Hamelin' fountain grass, except all treatments responded quadratically $(P<0.05$; Fig. 2B). Interactions between seawater salt spray concentrations and days after treatment initiation (DATI) were found for both species $(P<0.0001)$. Data indicate that height of 'Gracillimus' maiden grass is sensitive to increasing concentrations of seawater salt spray and was reduced relative to plants not exposed to seawater salt spray. 'Hamelin' fountain grass heights were similar among $0 \%, 25 \%$, and $50 \%$ seawater salts spray treatments, but grasses treated with $100 \%$ seawater salt spray declined more rapidly, resulting in shorter plants (Fig. 2B). This agrees with the findings of Hunter and $\mathrm{Wu}$ (2005), who observed leaf chlorosis and necrosis as symptoms of salt stress in tufted hairgrass (Deschampsia caespitosa) and california melicgrass (Melica californica) after exposure to $1500 \mathrm{mg} \cdot \mathrm{L}^{-1} \mathrm{NaCl}$. Marcum (1999) also reported chlorotic leaf area as an indicator of salinity injury after exposing several forage and turfgrasses to increasing salinities up to 600 $\mathrm{mol} \cdot \mathrm{m}^{-3} \mathrm{NaCl}$. As DATI and seawater salt spray concentrations increased, chlorosis and necrosis increased.

All seawater salt spray concentrations increased quadratically for ' $G r a-$ cillimus' maiden grass except plants treated with $100 \%$ seawater salt spray, which did not flower during the experiment $(P<0.05$; Fig. $3 A)$. Inflorescence numbers for 'Gracillimus' maiden grass treated with $0 \%, 25 \%$, and $50 \%$ seawater salt spray increased with decreasing seawater salt spray concentration, although flowering did not occur until 70 DATI (Fig. $3 \mathrm{~A})$. Inflorescence number for all treatments of 'Hamelin' fountain grass increased quadratically until 56 DATI $(P<0.05$; Fig. $3 \mathrm{~B})$. At 56 DATI, grasses treated with $100 \%$ seawater salt spray began to show decreased inflorescence numbers, resulting in a substantial decline relative to other concentrations (Fig. 3B). Interactions between seawater salt spray concentration and DATI were found for both species $(P<$ $0.0001)$. However, 'Hamelin' fountain grass inflorescence numbers were similar $(P>0.05)$ among grasses treated with $0 \%, 25 \%$, and $50 \%$ seawater salt spray throughout the experiment (Fig. 3B). Similar results were found in the final inflorescence numbers of 'Gracillimus' maiden grass receiving the same treatments. Hunter and $\mathrm{Wu}$ (2005) found no effect of salinity on flowering in native California grass species. In contrast, Munns and Rawson (1999) observed acceleration in the reproductive mode of plants grown at either 100 or 175 $\mathrm{mol} \cdot \mathrm{m}^{-3} \mathrm{NaCl}$. In this experiment, no difference in flowering was observed at low concentrations of seawater salt spray whereas decreased flowering occurred at higher concentrations of seawater salt spray.

Throughout the experiment, visual ratings of 'Gracillimus' maiden
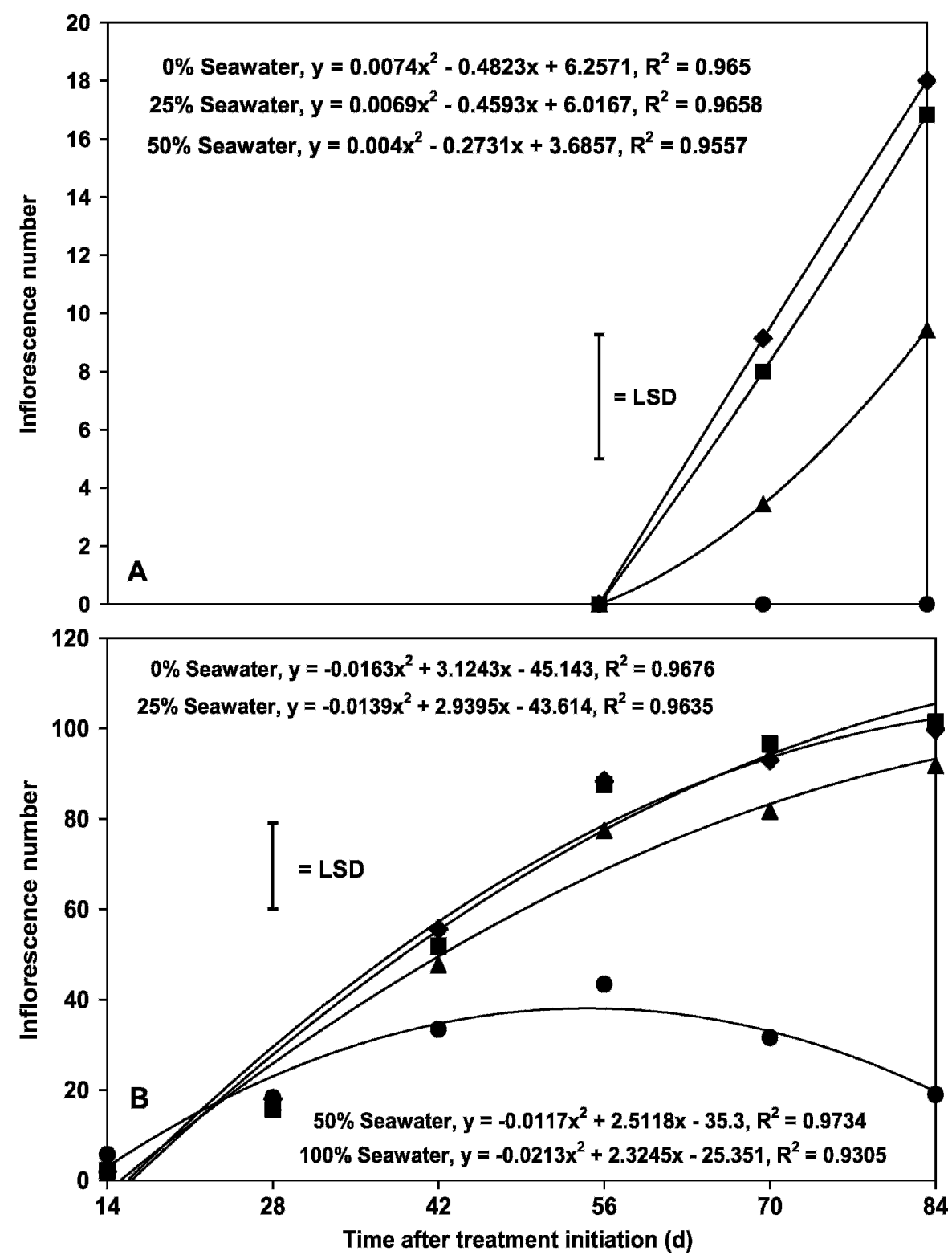

Fig. 3. (A, B) Mean inflorescence numbers for 'Gracillimus' maiden grass (A) and 'Hamelin' fountain grass $(B ; \mathbf{n}=7)$ treated with four foliar-applied seawater salt spray concentrations: $0 \%(\checkmark), 25 \%(\triangle), 50 \%(\square)$, and $100 \%(\bullet)$ per event over an 84-d period in central Florida. The vertical bars represent Fisher's protected LSD at $\alpha=0.05$. 
grass and 'Hamelin' fountain grass were inversely related to salt spray level. Lower visual ratings were the result of the presence of chlorotic and necrotic leaves.

Plants treated with $100 \%$ seawater salt spray displayed reduced height, inflorescence number, and visual ratings (Fig. 2). In addition, biomass of both species of plants decreased with increasing seawater salt spray concentrations (Fig. 1). Of the two grass cultivars, 'Gracillimus' maiden grass showed significant height and inflorescence number reduction across seawater salt spray concentrations, whereas 'Hamelin' fountain grass only showed significantly reduced height and inflorescence number at the $100 \%$ seawater salt spray rate. Under these experimental conditions, height and flowering of 'Hamelin' fountain grass are less sensitive to seawater salt spray than 'Gracillimus' maiden grass. Neither plant is tolerant of frequent exposure to $100 \%$ seawater salt spray, but at reduced levels of seawater salt spray, 'Hamelin' fountain grass appears to be a more suitable selection for landscape use.

\section{Literature cited}

Alshammary, S.F., Y.L. Qian, and S.J. Wallner. 2004. Growth response of four turfgrass species to salinity. Agr. Water Mgt. 66:97-111.

Belligno, A., L. Cutore, M. Di Leo, V. Sardo, and R. Brancato. 2002a. Response of two grasses to irrigation with diluted seawater. Acta Hort. 573:353-356.

Belligno, A., F. La Loggia, F. Sambuco, V. Sardo, and R. Brancato. 2002b. Salin- ity tolerance in elytrigia (Agropyron elongatum). Acta Hort. 573:349-351.

Benes, S.E., R. Aragues, S.R. Grattan, and R.B. Austin. 1996. Foliar and root absorption of $\mathrm{Na}$ and $\mathrm{Cl}$ in maize and barley: Implications for salt tolerance and screening and the use of saline sprinkler irrigation. Plant Soil 180:75-86.

Bernstein, L. and L.E. Francois. 1975. Effects of frequency of sprinkling with saline waters compared with daily drip irrigation. Agron. J. 67:185-190.

Crossett, K.M., T.J. Culliton, P.C. Wiley, and T.R. Goodspeed. 2004. Population trends along the coastal United States: 1980-2008. National Oceanic and Atmospheric Administration, Washington, DC.

Edwards, R.S. and G.D. Holmes. 1968. Studies of airborne salt deposition in some north Wales forests. Forestry 41: 155-174.

Grattan, S.R., E.V. Mass, and G. Ogata. 1981. Foliar uptake and injury from saline aerosol. J. Environ. Qual. 10:406-409.

Grattan, S., A. Royo, and R. Aragues. 1994. Chloride accumulation and partitioning in barley as affected by differential root and foliar salt absorption under saline sprinkler irrigation. Irr. Sci. 14:147-155.

Gulzar, S., M.A. Khan, and I.A. Ungar. 2003. Effects of salinity on growth, ionic content, and plant-water status of Aeluropus lagopoides. Commun. Soil Sci. Plant Anal. 34:1657-1668.

Howell, D.C. 2004. Fundamental statistics for behavioral sciences. Thomson Wadsworth, Stamford, CT.

Hunter, K.A. and L. Wu. 2005. Morphological and physiological response of five California native grass species to moderate salt spray: Implications for land- scape irrigation with reclaimed water. J. Plant Nutr. 28:247-270.

Karschon, R. 1964. Chloride scorch due to wind-borne salt in Eucalyptus gomphocephata. Israel Forester 14:42-45.

Malloch, A.J. 1972. Salt spray deposition on the maritime cliffs of the Lizard Peninsula. J. Ecol. 60:103-112.

Marcum, K.B. 1999. Salinity tolerance mechanisms of grasses in the subfamily Chloridoideae. Crop Sci. 39:1153-1160.

Marcum, K.B. 2001. Salinity tolerance of 35 bentgrass cultivars. HortScience $36: 374-376$.

Marcum, K.B. and C.L. Murdoch. 1994. Salinity tolerance mechanisms of six C4 turfgrasses. J. Amer. Soc. Hort. Sci. 119:779-784.

Marcum, K.B., M. Pessarakli, and D. Kopec. 2005. Relative salinity tolerance of 21 turf-type desert saltgrasses compared to bermudagrass. HortScience $40: 827-829$

Munns, R. and H. Rawson. 1999. Effect of salinity on salt accumulation and reproductive development in the apical meristems of wheat and barley. Aust. J. Plant Physiol. 26:459-464.

Qian, Y.L., S.J. Wilhelm, and K.B. Marcum. 2001. Comparative response of two kentucky bluegrass cultivars to salinity stress. Crop Sci. 41:1895-1900.

Snedecor, G.W. and W.G. Cochran. 1980. Statistical methods, 7th ed Iowa State University Press, Ames, IA.

Westcot, D.W. and R.S. Ayers. 1984. Irrigation water quality criteria, p. 3-37. In: G.S. Pettygrove and T. Asano (eds.). Irrigation with reclaimed municipal wastewater: A guidance manual. California State Water Control Board, Sacramento, CA. 